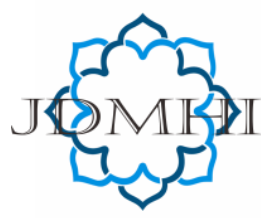

email: jdmhi@walisongo.ac.id

Journal of Digital Marketing and Halal Industry

ISSN: 2716-4810 (print) ISSN: 2716-4802 (online)

\title{
The Effect of Business Literation on SMEs Performance with Mediation of Risk Management and Entrepreneurial Self Efficacy
}

\section{Bambang Widarno}

Doctoral Management Program, Sultan Agung Islamic University, Semarang, Indonesia

\section{A R T I C LE I N F O}

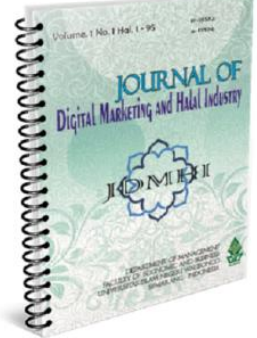

Article history:

Received 7 March 2021

Accepted 22 April 2021

Published 30 April 2021

Keywords:

Business Literacy,

Entrepreneurial Self-Efficacy,

Enterprise Risk Management,

SMEs Performance.

\section{A B S T R A C T}

Literacy is the main prerequisite for intellectual growth and the ability to learn to generate new knowledge. This study aims to analyze the effect of business literacy on the performance of SMEs, either directly or indirectly by including the Entrepreneurial Self-Efficacy (ESE) and Enterprise Risk Management (ERM) variables as mediation and moderation variables, respectively. The approach of this article is thought or conceptual based on intellectualization and reflects the prospects and impact of digital marketing. This study uses a critical system to analytically review digital marketing literature and relate it to research results. The data analysis technique used is descriptive. Based on the results of tracking and analysis, there has never been any previous research that examines business literacy, ESE, ERM, and SME performance in one model. The implication of social justice in the field of business literacy is through the existence of a business application system that is socialized to business people. Business information can enhance or even suppress the effects of entrepreneurial self-efficacy. ERM as a planned action is a control activity, which can be perceived not as an obstacle to gaining profits, but to get the expected performance results.

@2021 Journal of Digital Marketing and Halal Industry

\section{Introduction}

literacy is a fundamental skill to empower people in the development of reason, logic, systematic thinking, and research. Literacy is the main prerequisite for intellectual growth and learning ability. Without literacy, one cannot reach the source of human knowledge and use it to generate new knowledge. The progress of human civilization should be related to the level of literacy and its development in society (Zare et al., 2017). People who ignore financial and economic matters i.e. do not have sufficient business literacy are not sufficiently familiar with concepts such as costs and savings, and because of this lack of knowledge, will have many problems in business management and

* Corresponding author.email: bambangwidarno@std.unissula.ac.id DOI: http://dx.doi.org/10.21580/jdmhi.2021.3.1.7745 
will not be able to survive the market turmoil. competitive.

Insufficient business literacy (BL) will affect business decision-making (Zare et al., 2017). In the current development, the concept of literacy is no longer only associated with information and media but has touched on certain aspects of human life more specifically (Pawit \& Encang, 2017). In the context of the use of information and communication technology, for example, literacy is attached to the ability of people to use computer equipment in terms of both hardware and software. Now, literacy has touched many aspects of human life, including business. Business literacy is certainly broader than financial literacy, marketing literacy, human resource literacy, and so on.

The number of business cases and threats to the financial crisis must be addressed properly. Business actors act on business information but lack the skills to criticize the forces that make them face the risk of endangering themselves and their company, community, and environment. Ideologies such as free-market capitalism encourage the majority of business people to imagine business information as an impartial item that is freely regulated by the forces of supply and demand specifically designed for their consumption. Information literacy concepts and critical evaluation of sources are needed to help business people think about solving problems and making decisions.

The making or consumption of information is influenced by one's beliefs and attitudes (Fink, 1989). People who have business information literacy can create, find, organize, and evaluate business information. Developed countries through the Association to Advance Collegiate Schools of Business (AACSB) require business schools to demonstrate a commitment "to address, involve and respond to current and emerging corporate social responsibility issues (for example, diversity, sustainable development, environmental sustainability, and globalization) of economic, cross-cultural activities) through policies, procedures, curriculum, research and/or outreach activities" to receive accreditation.

The classic problem of MSMEs is the inconsistency of business actors and consequently, it is difficult to improve SME performance. This shows that novice entrepreneurs in MSMEs have limited knowledge about business management. This condition may occur due to literacy entrepreneurship among business actors. Business literacy serves as the cutting-edge paradigm in assessing individual business development-related achievements. Business literacy is very important because most people who want to open themselves to business have limited knowledge of financial management, tax issues, management credit, and developing business projections in the long term.

The importance of individual business literacy is reflected in several aspects such as risk aspects and functional aspects (product, marketing, finance, and human resource management). Chao, et.al, (2017) suggested that researchers better identify the factors that moderate company performance. The purpose of this study is to analyze the effects of business literacy on SME performance, both directly and indirectly by including the Entrepreneurial Self-Efficacy (ESE) and Enterprise Risk Management (ERM) variables 
respectively as mediating and moderating variables. The value of this research is that based on the results of tracking there has never been a previous study that examines business literation, ESE, ERM, and the performance of SMEs in one model. The scope of this study is on the experiences of individuals who have been involved in the business world. Research Calderon et al. (2013) uses business literacy equations with training activities or technical guidance both inside and outside the classroom, where instructors emphasize practical examples and encourage "students" to connect concepts with their own business.

\section{Literature Review}

\section{Business Literacy and Entrepreneurial Self- Efficacy}

An organization is at the forefront of attracting customers, managing business processes is the act of overall management of an organization. Although it requires an understanding of management practices and a clear definition of the role and process of decision-making as part of the business management process, the existence of a process-based information system and trained personnel, and a culture that embraces business processes is essential. The roots of business process management lie in a variety of approaches, such as business process reengineering, total quality management (TQM) Six Sigma business process modeling, and information system processes (workflow management systems and service-oriented architectures) (Zare et al., 2017) ). One of the characteristics of a successful organization is a constantly changing implementation. Although the best mode is almost impossible, an organization can approach the state of business development. Given the importance of process orientation, business information systems process maturity allows managers to view the current status of the organization from a process management maturity perspective.

By analyzing current and desired states, managers can identify weaknesses in the organization and fix them, and the results of the improvement process are customer loyalty, productivity, and business excellence (Rosemann \& de Bruin, 2004). The unpredictable growth of information and technology concerning storage, organization, and access to information is a distinguishing feature of this period. Currently, more than 34 types of literacy needed have been identified and analyzed. Among them are useful and modern cultural literacy, education, social literacy, political literacy, economic literacy, media literacy, information literacy, information literacy, computer literacy, internet literacy, workplace literacy, family literacy, legal literacy technology literacy, network literacy, literacy communication, tool literacy, resource selection literacy, spiritual literacy, health literacy, artistic literacy, audiovisual literacy, critical literacy, military literacy, environmental literacy (ecological) and so on can be cited (Zare et al., 2017).

The concept of literacy is related to the concept of acquisition. This acquisition shows that skills and competencies related to literacy are not things that are organic and are in the process of spontaneous development in humans, for example. Child walking is a physiological problem and is due to their growth over time and occurs regardless of education and effort. On the other hand, literacy, although requiring specific growth 
areas is not equivalent to them and in addition, requires effort, planning, and training (Sajadieh, 2015). So business literacy is "knowledge and understanding of the financial, accounting, marketing and operational functions of an organization." Efforts to improve literacy are carried out through the implementation of education that begins with a fundamental introduction to the business, including the characteristics, benefits, costs, and risks of financial products and services as well as personal financial management which is ultimately expected to bring positive changes to business behavior.

Education needs adequate infrastructure support and is implemented by taking into account planned and measurable principles, achievement-oriented, sustainability, and collaboration. Business information literacy (BIL) helps businesses "recognize when information is needed and have the ability to find, evaluate, and use effectively the information needed" (Cooney, 2005). Users may need to think about questions, gather information, maybe make assumptions about information about the business they find (Jacobson, 1994). Self-efficacy has been used in several studies as a mediating variable and has been identified as a far more consistent predictor of behavior and behavior change (Zhao et al., 2005; Bailey and Austin, 2006). Several studies have examined the mediating role of self-efficacy in a variety of contexts.

Empirical findings over the years have supported Bandura's (1986) argument that self-efficacy beliefs mediate the relationship between various variables and achievement of performance in a particular domain. Hejazi et al. (2009) found that self-efficacy in different domains indirectly played a facilitative role in the process of cognitive involvement to realize more successful performance driven by the desire to achieve other than the skills they possessed.

Proposition 1: Business literacy will strongly influence the entrepreneurial self-efficacy of business managers.

\section{Business Literacy and Enterprise Risk Management}

Based on the specific findings of SMEs from the articles reviewed for this paper, these five steps are now described in more detail in the following subsections. Notably, case studybased research (Gao et al., 2013) suggests that risk management practices in SMEs may be very informal, which in turn hinders sharing and thus also builds risk management capacity in SMEs. However, Brustbauer (2014) found many examples of SMEs taking a very proactive approach to risk management. Thus, in the published literature, there are rather informal risk management incidents and a more formal and proactive approach in SMEs. Enterprise risk management (ERM), quickly, establishes itself as the dominant paradigm of corporate risk management. The past two decades have witnessed a large increase in demand for ERM and an increase in corporate risk governance more generally.

Pressure from outside stakeholders has been an important influence on this development which reflects a corporate scandal involving excessive risk-taking (Gates, 2006). The distinguishing feature of ERM is that it represents risk management seen from the perspective of the company's top executives and directors. This is not about project risk or investment risk or specific risk. The 
perspective taken is how to manage the net, the aggregate risk exposures of the entire company, and how to frame the willingness and capacity of the company to accept these exposures.

ERM consists of risk governance and risk aggregation (Hakan, 2019). ERM is related to two optimization problems. When risk management is implemented successfully, the company has an optimized business risk portfolio, that is, risks that arise as a natural consequence of doing business. In her list of best practices for business instruction originating from studies, Fiegen (2011) highlights the importance of using conceptual business models that are already familiar to users. The model can include business and marketing models, but it can also include an ethical conception model.

Proposition 2: Business literacy will have a strong influence on company risk management.

\section{Business Literacy and SME Performance}

A large literature on companies in developing countries found that companies often run inefficiently (Bloom et al. 2013; Bruhn, Karlan, and Schoar 2012), this can have several causes from the lack of credit markets, to imperfections in the goods market and so on. Among these reasons, entrepreneurs may not have the basic business skills needed to run a business, such as an understanding of costs, sales, profits, pricing, marketing, and competition.

Calderon et.al. (2013) from the results of his research observations found that business operators assigned to "care" (technical guidance about business) get higher profits, have greater incomes, serve more clients, are more likely to use formal accounting techniques, and are more likely to be registered at the government. Calderon et.al. (2013) presents a simple experience and learning model that helps interpret results, and are consistent with theoretical predictions, which find that "low quality" entrepreneurs are most likely to get out of their post-care business, and that the positive impact of " treatment "increased in entrepreneurial quality.

Proposition 3: Business literacy will have a strong effect on the performance of SMEs.

\section{Entrepreneurial Self-Efficacy and SME Performance}

Entrepreneurial self-efficacy (ESE) has been defined by researchers from various perspectives. ESE is an important construct in entrepreneurial research, which captures the confidence of entrepreneurs in completing entrepreneurial tasks (Chao, et.al., 2017; Baum et al. 2001; Baron et al. 1999). Another opinion defines ESE as a belief in personal ability to complete the process of starting a business (Chen et al. 1998; Segal et al. 2005). Entrepreneurial self-efficacy is different from perceived behavioral control. Whereas control beliefs are defined as people's beliefs regarding the existence of factors that can help in carrying out a behavior, perceived behavioral control refers to whether someone considers doing certain behaviors easy or difficult (Ajzen 1991).

Self-efficacy and perceived behavioral control are two different constructs (Tavousi et al. 2009). Self-efficacy has a broad theoretical foundation and supports empirical research in predicting future performance (Bandura, 1978). Based on social learning theory reasons, ESE can cause task-specific effects. In particular, as entrepreneurs have an ESE, which means that they hold a strong belief in 
their ability to complete tasks in the field of entrepreneurship (Bandura \& Cervone, 1986), they set challenging goals, demonstrate persistence, invest effort in entrepreneurial tasks, and recover quickly from failures (Bandura, 1991). For example, entrepreneurs with ESE tend to set challenging growth expectations for their company and persist in their quest to achieve these goals. Furthermore, the effect of the effort invested is reflected in performance (Wood \& Bandura, 1989).

In other words, ESE converts entrepreneurial beliefs into endeavors, which, in turn, improve company performance. Empirical evidence also supports this positive relationship between ESE firm performance (Mcgee et al., 2009). For example, Forbes, (2005) surveyed new business founders and identified a positive relationship between ESE and new business revenue performance. Similarly, Baum \& Locke, (2004) found that ESE had the strongest direct effect on enterprise growth among the predictors they studied. Thus, based on theory and empirical results, we estimate that ESE is positively related to firm performance.

Several previous studies from various countries have investigated the effects of entrepreneurial self-efficacy on the intention to start a business based on a student sample, and the majority of the results indicate that there is a positive relationship between selfefficacy and entrepreneurial intentions (Chen et al. 1998; Jung et al. 2001; Segal et al. 2005, Wilson et al. 2007; Borchers and Park, 2010; Byabashaija and Katono, 2011). Research Tsai, et.al. (2014) states that entrepreneurial self-efficacy positively influences intention through attitudes towards entrepreneurship and planned entrepreneurial control.

Preposition 4: Entrepreneurial self-efficacy of business managers affecting the performance of SMEs

The Role of Moderating ERM in the Relationship of ESE and SME Performance

Based on this logic, people who are very confident in their ability to carry out entrepreneurial activities are more likely to have a low-risk perception in doing this activity (Liñán 2008). Self-efficacy theory contributes to explain the relationship between beliefs, attitudes, intentions, and behavior. People's intentions and behavior are greatly influenced by their beliefs to effectively complete the given task (Bandura et al. 1980). The theory of planned behavior shows that people's control beliefs influence perceived behavioral control and attitudes toward behavior, affecting their subsequent intentions and behavior (Ajzen 1991).

According to this perspective, in addition to the direct relationship between entrepreneurial efficacy and entrepreneurial intentions, entrepreneurial self-efficacy is indirectly related to entrepreneurial intentions through attitudes towards entrepreneurship and behavioral control felt by business actors, including the existence of intrinsic and extrinsic motivation (Deci et al. 1999). Tsai, et.al. (2014) in their study found a direct effect of entrepreneurial self-efficacy on intention, diminished with increasing subjective norms. In contrast, the effect of indirect intention on entrepreneurial selfefficacy through attitudes towards entrepreneurship and planned entrepreneurial control, increases with 
increasing subjective norms. Besides Tsai, et.al. (2014) shows that subjective norms positively influence entrepreneurial intentions.

The results of the study by Rehman \& Anwar, 2019) show that business strategy has a significant influence on the performance of SMEs and the risk of management companies. In addition, part of the company's risk management mediates the relationship between business strategy and SME performance. This study finds that firms with unique business strategies support formal risk management practices which in turn facilitate superior performance in the market. Risk management can help SME managers to identify significant risks that can jeopardize the success or existence of the company in time to deal with them efficiently (Brustbauer, 2014). Misjudging or failing to recognize risks can, in the worst case, have catastrophic consequences, from loss of customers to damaging liabilities, environmental damage, and possibly, even bankruptcy.

However, many SMEs do not or do not adequately implement risk management practices, in large part because they are unable to rededicate resources due to their constraints (Marcelino-Sádaba et al., 2014). The results of the study by Songling et al., (2018) show that the company's risk management practices significantly affect the competitive advantage and performance of SMEs. Competitive advantage mediates in part the relationship between firm risk management practices and SME performance. In addition, financial literacy significantly moderates the relationship between firm risk management practices and competitive advantage. Companies are advised to apply formal corporate risk management practices to gain competitive advantage and superior performance. Top managers need to have sufficient financial education so that they can efficiently practice risk management to gain a competitive position in the market

Based on the logic above people who are very confident in their ability to run a business are more likely to have a lower risk perception in conducting business activities (Liñán 2008). ERM is a control activity, which can be perceived to avoid risk to obtain the results as expected, not nearly the business of making a profit. Perceived external perceptions can suppress the influence of entrepreneurial selfefficacy. Tsai et.al.'s model (2014) contributes to advancing the use of planned behavior theory and can be used to make a person a reliable entrepreneur, and carrying out risk management is a planned action.

Proposition 5: The effect of entrepreneurial selfefficacy on SME performance will be better if the business manager carries out risk management.

\section{The Method, data, and analysis}

The methodology of this article is thought or conceptual based on intellectualization and reflects the prospects and impact of digital marketing. This study uses a critical system to analytically review digital marketing literature and relate it to research results. The data analysis technique used is descriptive. The conceptual model is described in Figure 1. 


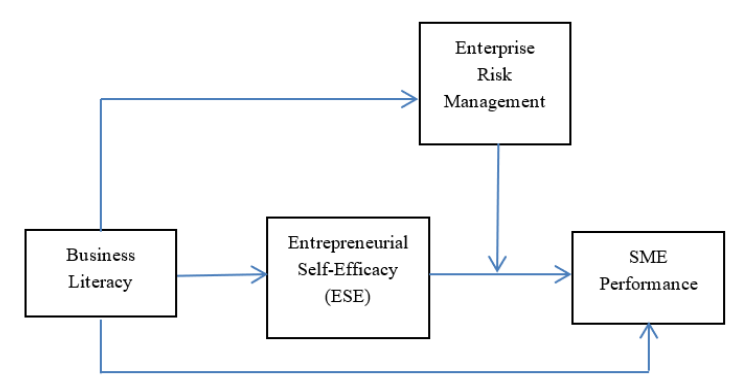

Figure 1. Conceptual Framework

\section{Result and Discussion}

People usually receive resources and support from family members or other people who are very bound when starting a business (Greve and Salaff 2003). Family and other important people are the origins of subjective norms. These resources can encourage people who are confident in their ability to carry out entrepreneurial activities and feel more positive about entrepreneurship, resulting in a greater willingness to start and run a business. This subjective norm can also increase the effect of entrepreneurial control on that person. The interaction between extrinsic and intrinsic motivation has suggested that the controlling property of external influences inhibits intrinsic orientation associated with behavior, reducing the effect of intrinsic motivation (Deci et al. 1999; Fu et al. 2010). External perceptions perceived by a person can suppress the effect of self-efficacy entrepreneurship. Perceived external perceptions can suppress the influence of entrepreneurial self-efficacy, including those obtained from business information literacy. ERM as a planned action is a control activity, which can be perceived to avoid risk to obtain the results as expected, rather than hampering efforts to obtain profits. Hakan
(2019) proposes to see ERM as a solution, which is a set of mechanisms to address two common risk management problems faced by companies. the problem of risk management agency and information is the most important thing in the management and the basis for making the right decision lies in the problem of completeness of the information. Information can be obtained in a limited and unlimited way, the task of a business is to explore as much information as possible for better business management. Critical business information literacy does not reflect a new set of responsibilities but rather a deliberate approach to traditional business information literacy (Stonebraker et.al, 2017). Further implications of social justice in the field of business literacy through a business application system that contains scientific publications, conference results, and meetings of professional organizations, which are disseminated to business groups. Perceived external perceptions can suppress the influence of entrepreneurial self-efficacy, including those obtained from business information literacy. ERM as a planned action is a control activity, which can be perceived to avoid risk to obtain the expected performance results, rather than hampering efforts to gain profits.

\section{Conclusion}

Based on the discussion above, the author concluded that all prepositions proposed in the section of the literature review are accepted. Below are the prepositions; Business literacy will strongly influence the entrepreneurial self-efficacy of business managers. Business literacy will have a strong influence on company risk management.

\section{http://journal.walisongo.ac.id/index.php/JDMHI/index} DOI: http://dx.doi.org/10.21580/jdmhi.2021.3.1.7745 
Business literacy will have a strong effect on the performance of SMEs. The entrepreneurial self-efficacy of business managers affects the performance of SMEs. The effect of entrepreneurial self-efficacy on SME performance will be better if the business manager carries out risk management.

\section{Recommendations}

For further research, this preposition can then be tested empirically, considering that research on MSME literacy is still quite limited, so this research needs to be further developed.

\section{References}

Ajzen, I. (1991). The theory of planned behavior. Organizational Behavior and Human Decision Processes, 50(2), 179211.

Bailey, C. \& Austin, M. 2006. 360 Degree Feedback and Developmental Outcomes: The Role of Feedback Characteristics, Self-Efficacy and Importance of Feedback Dimensions to Focal Managers' Current Role. International Journal of Selection and Assessment, 14, 51-66.

Bandura, A. 1986. Social foundations of thought and action, Englewood Cliffs, NJ Prentice Hall.

Bandura, A. (1978). Self-efficacy: Toward a unifying theory of behavioral change. Advances in Behaviour Research and Therapy, 1(4), 139-161. https://doi.org/10.1016/01466402(78)90002-4

Bandura, A. (1991). Social cognitive theory of self-regulation. Organizational Behavior and Human Decision Processes, 50(2), 248-287.

https://doi.org/10.1016/0749.

5978(91)90022-L

Bandura, A., \& Cervone, D. (1986). Differential engagement of self-reactive influences in cognitive motivation. Organizational Behavior and Human Decision Processes, 38(1), 92-113. https://doi.org/10.1016/0749. 5978(86)90028-2

Baron, R. A., Markman, G. D., et al. (1999). Cognitive mechanisms: Potential differences between entrepreneurs and non-entrepreneurs. In P. D. Reynolds \& W. D. Bygrave (Eds.), Frontiers of entrepreneurship research. Wellesley: Babson College.

Baum, J. R., Locke, E. A., \& Smith, K. (2001). A multidimensional model of venture growth. Academy of Management Journal, 44(2), 292-303.

Baum, J. R., \& Locke, E. A. (2004). The relationship of entrepreneurial traits, skill, and motivation to subsequent venture growth. Journal of Applied Psychology, 899(4), 587-598. https://doi.org/10.1037/00219010.89.4.587

Brustbauer, J. (2014). Enterprise risk management in SMEs: Towards a structural model. International Small Business Journal: Researching Entrepreneurship, 34(1), 70-85. https://doi.org/10.1177/02662426145 42853

Borchers, A., \& Park, S. A. (2010). Understanding entrepreneurial mindset: 
a set of entrepreneurial self-efficacy, locus of control, and intent to start a business. Journal of Engineering Entrepreneurship, 1(1), 51-62.

Bloom, Nicholas, Benn Eifert, Aprajit Mahajan, David McKenzie, and John Roberts. 2013. "Does management matter? Evidence from India." The Quarterly Journal of Economics, 128(1): $1-51$.

Bruhn, Miriam, Dean S Karlan, and Antoinette Schoar. 2012. "The impact of consulting services on small and medium enterprises: Evidence from a randomized trial in mexico." Yale University Economic Growth Center Discussion Paper, , (1010).

Byabashaija,W., \& Katono, I. (2011). The impact of college entrepreneurial education on entrepreneurial attitudes and intention to start a business in Uganda. Journal of Developmental Entrepreneurship, 16(1), 127-144.

Calderon, Gabriela, Jesse M. Cunha, \& Giacomo De Giorgi. 2013. Business Literacy and Development: Evidence from a Randomized Controlled Trial in Rural Mexico. Working Paper 19740 http://www.nber.org/papers/w19740 National Bureau of Economic Research 1050 Massachusetts Avenue Cambridge, MA 02138

Chao Miao, Shanshan Qian \& Dalong Ma. 2017. The Relationship between ntrepreneurial Self-Efficacy and Firm Performance: A Meta-Analysis of Main and Moderator Effects. Journal of Small Business Management, Volume 55, 2017 - Issue 1
Chen, C. C., Greene, P. G., \& Crick, A. (1998). Does entrepreneurial self-efficacy distinguish entrepreneurs from managers? Journal of Business Venturing, 13(4), 295-316.

Cooney, M. (2005). Business Information Literacy Instruction. Journal of Business $\mathbb{E}$ Finance Librarianship, 11(1), 3-25. doi:10.1300/J109v11n01_02

Deci, E. L., Koestner, R., \& Ryan, R. M. (1999). A meta-analytic review of experiments examining the effects of extrinsic rewards on intrinsic motivations. Psychological Bulletin, 125(6), 627-668.

Fiegen, A. M. (2011). Business Information Literacy: A Synthesis for Best Practices. Journal of Business $\mathcal{E}$ Finance Librarianship, 16(4), 267-288. doi:10.1080/08963568.2011.606095

Fink, D. (1989). Process and Politics in Library Research: A Model for Course Design. Chicago, IL: American Library Association.

Forbes, D. P. (2005). The effects of strategic decision making on entrepreneurial selfefficacy. Entrepreneurship: Theory and Practice, 29(5), 599-626. https://doi.org/10.1111/j.15406520.2005.00100.x

Fu, F. Q., Richards, K. A., Hughes, D. E., \& Jones, E. (2010). Motivatin salespeople to sell new products: the relative influence of attitudes, subjective norms, and self-efficacy. Journal of Marketing, 74(6), 61-76.

Gao, S. S., Sung, M. C., \& Zhang, J. (2013). Risk management capability building in 
SMEs: A social capital perspective. International Small Business Journal, 31(6), 677-700.

https://doi.org/10.1177/02662426114 31094

Gates, S. (2006), "Incorporating strategic risk into enterprise risk management: a survey of current corporate practice", Journal of Applied Corporate Finance, Vol. 18 No. 4, pp. 81-90.

Håkan Jankensgård, (2019) "A theory of enterprise risk management", Corporate Governance: The International Journal of Business in Society, https://doi.org/10.1108/CG-02-20180092

Hejazi, E., Shahraray, M., Farsinejad, M. \& Asgary, A. 2009. Identity Styles and Academic Achievement: Mediating Role of Academic Self-Efficacy. Social Psychology of Education, 12, 123-135.

Jacobson, T.E. (1994). Another Look at Bibliographic Instruction for Business Students. Journal of Business $\mathcal{E}$ Finance Librarianship, 1(4), 17-28. doi:10.1300/J109v01n04_03

Jung, D. I., Ehrlich, S. B., De Noble, A. F., \& Baik, K. (2001). Entrepreneurial selfefficacy and its relationship to entrepreneurial action: a comparative study between the US and Korea. Management International, 6(1), 41-53.

Liñán, F. (2008). Skill and value perceptions: how do they affect entrepreneurial intention. International Entrepreneurship and Management Journal, 4(3), 257-22.

Marcelino-Sádaba, S., Pérez-Ezcurdia, A., Echeverría Lazcano, A. M., \&
Villanueva, P. (2014). Project risk management methodology for small firms. International Journal of Project Management, 32(2), 327-340. https://doi.org/10.1016/j.ijproman.20 13.05.009

Mcgee, J. E., Peterson, M., Mueller, S. L., \& Sequeira, J. M. (2009). Entrepreneurial self-efficacy: Refining the measure. Entrepreneurship: Theory and Practice, 33(4), 965-988. https://doi.org/10.1111/j.15406520.2009.00304.x

Pawit M. Yusup \& Encang Saepudin. 2017. Praktik Literasi Informasi dalam Proses Pembelajaran Sepanjang Hayat. Jurnal Kajian Informasi \& Perpustakaan. Vol.5/No.1, Juni 2017, hlm 79-94

Rehman, A. U., \& Anwar, M. (2019). Mediating role of enterprise risk management practices between business strategy and SME performance. Small Enterprise Research, 26(2), 207-227. https://doi.org/10.1080/13215906.201 9.1624385

Rosemann, M., \& de Bruin, T. (2004). Application of a Holistic Model for Determining BPM Maturity. Proceedings of the AIM Pre-ICIS Workshop on Process Management and Information Systems, February, 46-60.

Sajadieh, N. (2015). Critique and approach to moral education from the perspective of human agency. Journal of Education Research Foundations, 5(2), 88-109.

Segal, G., Borgia, D., \& Schoenfeld, J. (2005). The motivation to become an entrepreneur. International Journal of Entrepreneurial Behaviour \& Research, 
11(1), 42-57.

Songling, Y., Ishtiaq, M., \& Anwar, M. (2018). Enterprise Risk Management Practices and Firm Performance, the Mediating Role of Competitive Advantage and the Moderating Role of Financial Literacy. Journal of Risk and Financial Management, 11(3), 35. https://doi.org/10.3390/jrfm11030035

Stonebraker, Ilana; Maxwell, Caitlan; Garcia, Kenny; and Jerrit, Jessica. 2017. "Realizing critical business information literacy: Opportunities, definitions, and best practices" (2017). Libraries Faculty and Staff Scholarship and Research. Paper 170. http://dx.doi.org/To link to this article:

http://dx.doi.org/10.1080/08963568.2 017. 1288519

Tavousi, M., Hidarnia, A. R., Montazeri, A., Hajizadeh, E., Taremian, F., \& Ghofranipour, F. (2009). Are perceived behavioral control and self-efficacy distinct constructs? European Journal of Scientific Research, 30(1), 146-152.

Tsai, Kuen-Hung, Hui-Chen Chang, \& Chen-Yi Peng. 2014. Extending the link between entrepreneurial self-efficacy and intention: a moderated mediation model. International Entrepreneurship and Management Journal. Springer Science+Business Media New York. DOI: $10.1007 / s 11365-014-0351-2$

Wilson, F., Kickul, J., \& Marlino, D. (2007). Gender, entrepreneurial self-efficacy, and entrepreneurial career intentions: implications for entrepreneurship education. Entrepreneurship: Theory and Practice, 31(3), 387-406.

Wood, R., \& Bandura, A. (1989). Social Cognitive Theory of Organizational Management. Academy of Management Review, 14(3), 361-384. https://doi.org/10.1016/B0-12-6574103/00217-8

Zare, H., Nayebzadeh, S., \& Roknabadi, A. D. (2017). Developing the scale of measuring business literacy of Iranian managers. International Journal of Business Management, 2(1), 40-47.

Zhao, H., Seibert, S. E. \& Hills, G. E. 2005. The Mediating Role of Self-Efficacy in The Development of Entrepreneurial Intentions. Journal of Applied Psychology, 90, 1265-1272. 